\title{
A sustainable planning approach for science parks: the case of the Southern Taiwan Science Park
}

\author{
S.-F. Kung \& Y.-C. Yen \\ Department of Urban Planning, National Cheng Kung University, \\ Taiwan, Republic of China
}

\begin{abstract}
This study addresses the new challenges facing the planning confliction for science parks and how it may be solved in a sustainable way in the case of the Southern Taiwan Southern Park (STSP). From the sustainable perspective, the problems can be classified into three parts. Firstly, the site is located in a lowlying area with flooding problems, which is also a historical area with highvalued cultural assets. Secondly, the semiconductor industries developing successfully in the northern region could not be embedded in local economic development; in contrast to TFT-LCD, they can already compete with other well-performing industries that have been developed over the past 20 years. Thirdly, there is a trend that science parks could be a growth-pole to accelerate regional development, but when this was put into practice, it interfered with local and central government's resource-seeking confliction and integration problems. In general, most of the problems are unanticipated and solved through learning by doing. In this paper, we conceptualize the process of how to govern the formation of the STSP, propose five important factors for the practical planning works, and hope this experience could be an important model for future planning.
\end{abstract}

Keywords: science parks, sustainable development, planning theory.

\section{Introduction}

Stanford Research Park in California, USA, is commonly regarded as the first planned science park in the world. It tries to attract entrepreneurs setting up companies or research and development facilities adjacent to a university. Due to 
its success, other industrialized countries have started to use this idea as the tool to stimulate high-tech industrial development since 1960s, such as Sophia Antipolis (1969), France, and Cambridge Science Park (1972), UK. After the 1980 s, there was the phenomenon of high-tech fantasies in terms of dramatically increasing numbers of established science parks $[6,11,12]$.

Taiwan has been promoting industrialization through supply of industrial estates since the 1960s; different kinds of industrial spaces, such as industrial parks and export processing zones, were established under different goals. Since the 1980 s, under the plan of upgrading industrial structure, Taiwan tried to encourage high-tech industries through developing research or science parks [9]. The Hsinchu Science-Based Industrial Park (HSIP) was established in 1980 as the first park on the island and is one of the worldwide famous examples [1,6]. In 1997, due to difficulties with the HSIP's expansion and the consideration of regional balance, the Taiwan government established its second science park in Tainan, first named the Tainan Science-Based Industrial Park (TSIP) and then expanded and renamed as the Southern Taiwan Science Park (STSP) in 2003. Rather than just copying the HSIP model with minor adjustment, the TSIP has witnessed significant improvement not only in terms of industrial park planning, but also for urban planning as a whole in Taiwan, and especially worthy of attention is its pro sustainability orientation.

The sustainable development concept has been widely accepted by spatial planning and design disciplines in recent decades. Environmental, social and economic sustainability are commonly regarded as the major domains to be considered in sustainable planning $[3,7,14]$, but until the present time such comprehensive approach has not been widely applied to economic-centered development projects in Taiwan, and indeed, not even in most of the common urban planning practices. Our central argument is that, under globalization and fast changing conditions, science park development cannot be successful without sustainable planning. Therefore, this paper attempts to share the success and failure experiences of science parks planning in Taiwan and to conceptualize the planning process of how to govern the formation of the STSP, especially in the context of the conflicts between different development goals, actors, and institutions. Finally, we will propose the possible planning thinking and regulation models of science parks. We hope this experience could be an important model for future planning.

\section{Park planning experience in Taiwan}

As a late-comer in industrialization, taking the development trajectory of the then more advanced industrial economies as reference, economic decisionmakers and planners in Taiwan had foreseen the need to upgrade its industrial structure from labor-intensive to technology-intensive in the mid-1960s. At that time, based on the success of rural reform and labor-intensive industrialization, Taiwan enjoyed for the first time after World War II a steady economic growth. Yet, based on some evaluations of the achievement of Taiwan's world renowned export processing zones (EPZs), these far-sighted development planners found that the EPZs had failed to enhance or embed local industrial technology, thus, 
the thought of building a new type of facility was raised. For example, Minister of Economic affairs K.T. Li (1969) raised the idea of a "research park" to enhance cooperation between academic institutions and industries in order to stimulate the formation of technology-intensive industries. This concept was modified and led to the reorganization and merging of three research institutions in Hsinchu and the establishment of the Industrial Technology Research Institute (ITRI) in 1973; this was undoubtedly an important step in the development of high technology industries and science parks in Taiwan. The concept of science parks was re-introduced to Taiwan in 1976 when Premier C. K. Chiang commenced the planning and construction of the HSIP, which was to be built as a campus-like environment on a large tract of land for science-based industrial activities. The HSIP was established in 1980, although in the beginning it was not generally considered as a realistic approach, being against Taiwan's contemporary labor-intensive industrial structure and low per capita GDP.

However, when it painstakingly overcame two downturn cycles and started fast growing in late 1980s, the park administration SIPA soon found it difficult to acquire land for further expansion because of landowners' resistance. The HSIP is an independent territory within the local district. From the very beginning until now, following the American model, science parks in Taiwan are a specialized form of industrial park that are dedicated to "R\&D-based industrial activities". As industrialists from local and overseas started to recognize Taiwan's potential in high technology industries, the HSIP became the hotspot of investment inquires, but SIPA began to face great pressure and started its new mission of finding a potential site outside of Hsinchu for expansion. From their direct supportive land uses plan of the HSIP, priority attention is not paid to the accommodation of other urban activities and residential areas account for only a small portion of the total park area, and they are distributed at peripheral locations [2]. Different from the top-down planning approach in HSIP, more and more bottom-up actions are emergent from local parties with fierce territorial competition [15]. Through a period of fierce battles among candidates, Tainan was eventually chosen as the site for the second science park project (Table 1).

The island-wide local interest in attracting the science park project did not cease after the first competition between 1989 and 1993; many new proposals came up with local and central elections, some of which did find good opportunities and received a positive reaction from central government. Thus, gradually, the number of science park projects accumulated. Some are proposals to accommodate spillovers from existing parks and some are initiatives to form new clusters. For the convenience of management, NSC and SIPA organized them into three groups in 2004 - Northern, Central and Southern Taiwan Science Parks, the oldest and biggest science park within each cluster serves as the mother park and regional administration center, other sites serving as satellite parks (Table 1). In 2006 the total number of science parks in operation, construction and planning mounted to twelve, Premier J. C. Su ordered NSC to organize a special team to evaluate the situation. The HSIP and STSP provided the major planning experience for the following projects; therefore, in this paper, we will take STSP as the major case to discuss. 
Table 1: $\quad$ Science park projects in Taiwan.

\begin{tabular}{|c|c|c|c|c|}
\hline & Name & Year & $\begin{array}{c}\text { Area } \\
\text { (ha) }\end{array}$ & Target Industries \\
\hline \multirow{6}{*}{$\begin{array}{l}\text { Northern } \\
\text { Taiwan } \\
\text { Science Park }\end{array}$} & Lungtan S.P. & 2004 & 76 & LCD \\
\hline & Hsinchu S.P. & 1980 & 632 & IC,C\&P,OE,TC,PM,BT \\
\hline & Hsinchu B.P. & 2003 & 38 & BT \\
\hline & Chunan S.P. & 1999 & 138 & $\mathrm{IC}, \mathrm{C} \& \mathrm{P}, \mathrm{BT}$ \\
\hline & Tungluo S.P. & 1999 & 353 & defense industry \\
\hline & Ilan S.P. & 2004 & 592 & TC \\
\hline Subtotal & & & & 1829 \\
\hline \multirow{4}{*}{$\begin{array}{l}\text { Central } \\
\text { Taiwan } \\
\text { Science Park }\end{array}$} & Houli S.P. & & 246 & $\mathrm{IC}, \mathrm{OE}$ \\
\hline & Taichung S.P. & 2002 & 413 & OE,BT,PM,IC \\
\hline & Huwei S.P. & & 97 & OE,LCD \\
\hline & Yunlin S.P. & 2003 & 97 & BT,OE,TC \\
\hline Subtotal & & & & 853 \\
\hline \multirow{3}{*}{$\begin{array}{l}\text { Southern } \\
\text { Taiwan } \\
\text { Science Park }\end{array}$} & Tainan S.P. & 1995 & 1038 & OE,BT,IC \\
\hline & Kaohsiung S.P. & 2000 & 570 & OE,TC,BT \\
\hline & Kaohsiung B.P. & 2004 & 8 & BT,MED \\
\hline Subtotal & \multicolumn{4}{|r|}{1616} \\
\hline Total & & & & 4298 \\
\hline
\end{tabular}

Note: BT: biotechnology, C\&P: computer \& peripherals, LCD: TFT-LCD, Med: medicine, OE: optoelectronics, PM: precision machinery, $\mathrm{TC}$ : telecommunications.

\section{The problems faced and solved in the STSP}

The TSIP was established in 1997 and renamed as the STSP in 2003. It consists of two sites - the Tainan Science Park (TSP) and the Kaohsiung Science Park (KSP), under one management body - the Southern Taiwan Science Park Administration (STSPA). Since it was the second science park in Taiwan, the planning and development of the STSP was highly influenced by its predecessor - HSIP. It is now the home of more than one hundred high technology firms, which altogether had provided 54,000 job opportunities by the end of 2007, with a total revenue of USD 17.5 billion. Although the STSP has tried to avoid the HSIP's failure experience by using detailed site assessment and making the "Special District Planning" in which the boundary of the planning is included "The Plan of the TSIP Special Zone" under STSPA management and "The Plan of STSP Specific District" under Tainan County management, it still faced the unpredicted problems and needed to develop new ways to solve them.

First, as the satellite park of the HSIP, the original industrial target for the STSP was to develop three industries, such as microelectronics and precision machinery, semiconductors, and agricultural biotechnology. For each target industrial cluster, a list of featured sub-industries was prepared and at a further level of detail, several promising products or technologies within each of these 
industries were also highlighted. Thus, the "industrial cluster" was the underlining concept of the TSIP industrial development planning. This is different from the HSIP, where no explicit expression concerning the "industrial cluster" can be found in its early planning document. However, the semiconductor and agricultural biotechnology industries developing successfully in the northern region could not be embedded in local economic development until now; in contrast to TFT-LCD, it can already compete with other highperformance industries developed over the last 20 years (Table 2). This phenomenon reflected the industrial targets for the STSP, which tend to be ad hoc under the consideration of the HSIP rather than based on theory or a complete study of regional context [4]. Kun and Chen [8] found the important factor is that none of the largest three industries in 1986 and 1996 can be regarded as having strong linkage with the STSP target industries or similarly with local industrial structure.

Table 2: $\quad$ Key industrial development index of the STSP.

\begin{tabular}{|l|r|r|r|r|r|r|}
\hline \multirow{2}{*}{ Industry } & \multicolumn{2}{|c|}{$\begin{array}{c}\text { Number } \\
\text { of tenants }\end{array}$} & \multicolumn{2}{c|}{$\begin{array}{c}\text { Number } \\
\text { of employees }\end{array}$} & \multicolumn{2}{c|}{$\begin{array}{c}\text { Revenue } \\
\text { (NT\$100mil.) }\end{array}$} \\
\cline { 2 - 8 } & 2001 & 2007 & \multicolumn{1}{c|}{2001} & \multicolumn{1}{c|}{2007} & \multicolumn{1}{c|}{2001} & \multicolumn{1}{c|}{2007} \\
\hline Integrated Circuits & 5 & 11 & 3498 & 11955 & 287.4 & 1302.1 \\
\hline Opto-electronics & 10 & 31 & 4518 & 35098 & 199.6 & 4026.7 \\
\hline Biotechnology & 2 & 18 & 326 & 950 & 1.5 & 30.9 \\
\hline Telecommunications & 5 & 8 & 565 & 819 & 5.5 & 15.4 \\
\hline Precision Machines & 1 & 32 & 427 & 3122 & 7.8 & 186.5 \\
\hline Computer \& Peripherals & 0 & 3 & 0 & 263 & 0 & 8.8 \\
\hline Others & 0 & 4 & 155 & 1858 & 0 & 18.3 \\
\hline Total & 23 & 107 & 9489 & 54115 & 501.8 & 5588.7 \\
\hline
\end{tabular}

Source: adopted from www.stsipa.gov.tw/web/

There are two important strategies to overcome these problems and build an industrial cluster. One is the coordination between the STSPA and local firms in which the STSPA assists them to upgrade their original product to the new level or invest in new, related industries. For example, the Chimei Group is a Tainanbased firm famous for chemical and foods products. After facing the tide of industrial restructuring, its first choice for locating new business was still in Tainan. Based on the firm's former experience of establishing a petrochemical industrial cluster, the idea was not only to build a plant, but also to build a vertically integrated industrial system within the Tainan area. With the technology transfer from the ITRI and the STSPA's negotiation, CMO was established in 1998 on a 19-hectare southwest corner site in the STSP. The total employees exceeded 17,000 in Taiwan and 32,000 globally in February 2008. It is now the second largest TFT-LCD producer in Taiwan, and the leading firm in the STSP TFT-LCD industrial cluster. The sector's total revenue in 2007 was approximately USD 10 billions. 
The other strategy is the land layout of the science park development plan and the setting up of target industries. The concept of "Specific Purpose District", combining traditional land development and industrial planning, could help the formation of industry-specific clusters and cope with the different needs of rapid industrial change. Through the application and negotiation process by the STSPA, investors may be introduced to the specialized zones as originally planned. For example, the STSPA divides TFT-LCD firms according to the manufacturing process with materials and components to the final product of LCD-TV. The are 30 firms in the cluster, including 13 materials and component firms, six module firms, 11 equipment firms, one photo mask firm, one driver IC firm, and two TFT-LCD panel firms. As most of the equipment firms are commonly classified as part of the precision machinery industry, the TFT-LCD industrial cluster in the STSP is mainly composed of opto-electronics firms and precision machinery firms, supported by some key chemical material producers. Moreover, in order to construct the complete TFT-LCD cluster by the consideration of transportation and assembling cost, the STSPA and Tainan County have the cooperation to develop the "LCD-TV Specific District" in the "STSP Specific District".

Secondly, in order to develop high-tech industries, the most important criterion for site selection from the west experience is whether the site is near the research university and research institute to provide innovation and technology transfer [4]. The principle for firms entering the STSP is that its innovation consumption needs to be equal to $3 \%$ of the revenue. However, Taiwan's economic miracle is based on massive manufacturing production; moreover, the industrial structure of the southern region of Taiwan is different from the northern region. Not so many firms in the southern region have the experience to work with the research and incubation center, and laboratories in the local area are different from the Silicon Valley [14] and the HSIP. In contrast, the local firms have the intensive technology cooperation of traditional industries with a local university in which there is less start-up from the spin-off. After the local firm - Cheimi - entered the STSP and with the emergence of TFT-LCD clusters, there was greater research cooperation with the National Cheng-Kung University and greater human resources with high quality migration from other regions and participation from the local university. By using a questionnaire, we found that the local flagship company can construct the special atmosphere for innovation and R\&D. Therefore, the research infrastructure is still important, but the local entrepreneurship and industrial characteristics may play more important roles in the output effect of this facility.

Thirdly, due to the improvement of technology in telecommunication and transportation, the phenomenon of firms clustering in a specific area, but dispersing in different scale (global, nation, region, local) under the consideration of environment and life cycle, will change the flow pattern of demand and supply in input factors and products, finally it will reflect in the space distribution in terms of type of industries and land lot size. Luger and Goldstein [10] studied the change pattern of parks from 1990 to 2004 and found that parks planned more recently are smaller in size. This is the result of the 
change of industrial structure under the trend of international product life cycle. Therefore, how to plan to reflect this situation is the important issue needing to be considered. The STSPA used the strategies to divide the "STSP" into three blocks for three original industrial targets and left 274 ha land for unspecified industries. Moreover, it also used the "Floating Zone" in the "STSP Specific District" under Tainan County management to prepare for the future needs. As a matter of the unpredicted land-consuming TFT-LCD industrial investment, the role of the STSPA and the result of these strategies are vital.

Fourthly, due to less storage and the higher price of urban land for the development of science cities and the industrial cluster, the NSC has to find nonurban areas for site selection and possible needs. Therefore, the designated site was selected to be flat and low-lying land of 638 hectares $(2,565$ acres $)$ with flooding problems, which used to be the Taiwan Sugar Corporation's immense sugarcane field, located across the border of three rural townships - Hsinshih, Shanhua and Anding - which altogether housed around 100,000 residents in the mid-1990s. Moreover, under the construction period after the site had been chosen, it was found that some areas were historical with high-valued cultural assets. According to the statistics, 25 relics were found in TSP and 14 have been unearthed. Whether it could be developed with high-tech industries in a sustainable way caused a lot of controversial debates at that time.

In the planning stage, the tool used to solve flooding problems is the combination of legal land use regulation and setting aside "green space" for the construction of flood detention ponds. However, the initial effect was small and the Tainan County Government proposed the idea named the "The Plan of STSP-Cambridge" with two points. Firstly, nine flood detention ponds were planned within the TSP and 10 flood detention ponds were planned within the "STSP Specific District" as landscape parks with the function of recreation and as the node of the network. After the fourth land use rezoning, the flooding problems have been solved. Secondly, the plan tried to connect the flood detention ponds with major drain ditches to construct a flowing network similar to the blue-green corridor in landscape ecological theory and make the water stay longer before flowing into the river. On the cultural side, the STSPA tried to combine the daily life with culture and high-tech in terms of building the "National Museum of Prehistory Tainan Branch".

Fifthly, there is a trend that science parks could be a growth-pole to accelerate regional development in terms of a science city or technopolis [1], but when this was put into practice, it interfered with local and central government's resourceseeking confliction and integration problems. In earlier Comprehensive Territorial Plans, it was proposed that the western corridor of Taiwan would proceed from a stage of five core cities in the 1960s to three metropolitan areas in the 1990s. Eventually, with high-speed surface transportation systems, the Tainan-Kaohsiung metropolitan area will be the core urban area of the south. Because Kaohsiung, the largest city, is quite far in the south, there are fierce territorial competitions with the Kaohsiung Metropolis moving east and southwards, while the Tainan Metropolis has diluted its own core to become more multi-nucleus (Figure 1), which finally led to the formation of two local 
development coalitions: Tainan Alliance (TTA) versus Kaohsiung-Pingtung Alliance (KKPA). For example, in order to attract more firms setting up in their own city, the Tainan City and Tainan County Government are competing for the subsidy offered by different government departments to construct fundamental infrastructure including Airports, National Museums, Bilingual Schools, etc. Therefore, contrary to the experience with the "Taian Technology Park" developed by the Ministry of Economic Association (MOEA), the STSPA has cooperated with the TTA in order to integrate all the resources and transfer the fierce competition to the positive side.

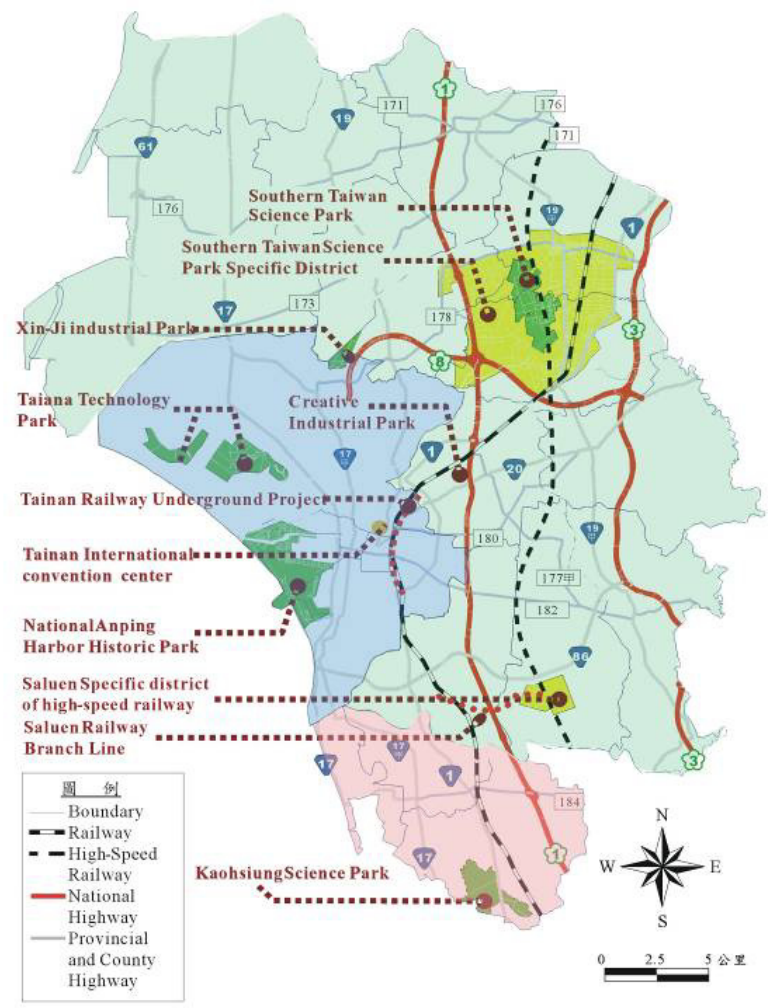

Figure 1: $\quad$ TTA related projects.

\section{Concluding remarks}

We know that the success of the STSP up until now is not the result of the original plan, but it has developed a new road to reconsider the planning of science parks in a more sustainable way. Therefore, this planning process could be conceptualized and transformed in advance to face future changes, although Taiwan already has famous industrial park building projects. In this section, we want to propose some possible planning ideas as follows. 
Firstly, the government's intervention in terms of public subsidy and building essential infrastructure is still the most important and necessary factor [9], but recently the ability to cooperate, negotiate and integrate have been stressed [10]. The STSPA played a positive cooperation role among local entrepreneurship, local government, and major research universities, and has been instrumental in pulling all these forces together to produce the synergy effect in which the ability to attract flagship companies in target industries, and to help energize local entrepreneurship are less discussed in the western literature.

Secondly, it is advisable to choose the target industries based on the regional and local industrial characteristics in the beginning stage of the planning process, because to develop a new industry in the space takes a long time to embed and manage with different local actors. Moreover, choosing the right local flagship company can construct a special atmosphere, and this has become the key factor that has changed the STSP from a satellite park of the HSIP into a science park with its own industrial identity. Chen et al. [2] have started to use this different way to draw up the next industrial development strategies for KSP.

Thirdly, the science city is the important form type for the sustainable development of science parks, but the planning and successful practice is very difficult. We think that the attitude of local government and the science park administration, the university and the research institute with a local context and industrial development, play important roles in the planning process.

Fourthly, diverse land use regulation could be an important tool in the formation of industrial cluster and sustainable parks. The STSPA and Tainan County used "land layout" and "special zone" for the industrial development and clusters, and "land readjustment", "land use rezoning" and "floating zone" for the formation of the "STSP Specific District", science city, flood detention ponds, and blue-green flow system.

Fifthly, "flexibility" in planning and "integrity" in the management of the STSPA, as well as coordination with local communities, are all important, for example, in adapting to industrial change, from a more general "microelectronics" to LCD, meeting the threat of high speed railway vibration by encouraging biotechnology, using an archaeological site to establish a museum and add more cultural elements to the science park, water flooding for retention ponds and entertainment, as well as wildlife preservation.

\section{References}

[1] Castells, M., Hall, P., Technopoles of the World: the Making of 21st Century Industrial Complexes. London, Routledge, 1994.

[2] Chen, P.-H., Y.-C. Yen, S.-F. Kun, Clustered Development for Innovation: Case Study of Hub of Telecommunications in Southern Taiwan Science Park. 2008 UNESCO-WTA International Training Workshop: Towards Creative Growth of Science Park and Innovative Cluster, 2008.

[3] Chou, T.L., The science park and the governance challenge of the movement of the high-tech urban region towards polycentricity: the 
Hsinchu science -based industrial park. Environment and Planning A, 39, pp. 1382-1402, 2007.

[4] Durao, D., Sarmento, M., Varela, V., Maltez, L., Virtual and real-estate science and technology park: a case study of Taguspark. Technovation, 25, pp. 237-244, 2005.

[5] Goldstein, H., Luger, M., Theory and Practice in High-Tech Economic Development. In: Theories of Local Economic Development, Bingham, R. (ed.), pp. 147-171, 1993.

[6] Kung, S.-F., The Role of Science Parks in the Development of High Technology Industries: with Special Reference to Taiwan. Cambridge, University of Cambridge, unpublished PhD Thesis, 1995.

[7] Kung, S.-F., Chung, K.-H., Sustainable industrial development planning in urban areas - from industrial ecology aspect. International Symposium on City Planning, 2000.

[8] Kun, S. F., Chen, C.-W., Role of Science Parks in the Formation of High Technology Industrial Clusters - the Case of Southern Taiwan Science Park. XXV IASP World Conference on Science \& Technology Parks, 2008.

[9] Luger, M., Goldstein, H., Science/Technology Parks and Regional Development Theory. Economic Development Quarterly, 4(1), pp. 64-78, 1990.

[10] Luger, M., Goldstein, H., Research Parks Redux: The Changing Landscape of The Garden. Technopolis Review, 1, pp.04-17, 2007.

[11] Markusen, A., Hall, P. and Glasmeier, A., High-Tech America: the what, how, where and why of the sunrise industries. Boston, Allen \& Unwin, 1986.

[12] Massey, D., Quintas, P., Wield, D., High-Tech Fantasies: Science Parks in Society, Science and Space. London, Routledge, 1992.

[13] National Science Council, Tainan Science-Based Industrial Park, National Science Council, Taipei, 1996 (in Chinese).

[14] Saxenian, A., Hsu, J.-Y. The Silicon Valley-Hsinchu Connection: Technical Communities and Industrial and Upgrading. Industrial and Corporate Change, 10(4), pp. 893-920, 2001.

[15] Yang, Y.-R., Su, I-J., Territorial Competition and Spatial Politics: A Case Study of Taiwan's Southern Science-based Industrial Park, Journal of Geographical Science, 31, pp. 35-81, 2002 (in Chinese). 